\title{
MODEL PICTORIAL SEBAGAI REPRESENTASI MENYELESAIKAN SOAL CERITA MATEMATIS
}

\author{
Agus Prianto \\ SMP Negeri 1 Jepara, Jl. Sersan Sumirat No.3 Jepara; agus.mumtaz@yahoo.co.id
}

\begin{abstract}
Abstrak. Tulisan ini menyajikan kajian tentang model pictorial sebagai representasi matematis dalam menyelesaikan soal cerita matematis. Kemampuan representasi matematis merupakan kunci dasar bagi siswa dalam menyelesaikan soal cerita matematis dan keberhasilan belajar matematika, sehingga kemampuan ini harus ditekankan, dikembangkan dan dimiliki siswa dalam pembelajaran matematika. Model Pictorial dapat digunakan sebagai langkah awal dalam merepresentasikan sekaligus memodelkan/mengilustrasikan maksud soal cerita matematis. Melalui pendekatan model Pictorial ini yang dipadukan dengan konsep aljabar dasar diharapkan akan dapat membantu semua siswa dalam memahami sekaligus menyelesaikan soal cerita matematis yang umumnya siswa mengalami kesulitan sehingga pada akhirnya siswa dapat mengembangkan kompetensi dan kemampuan matematisnya secara optimal.
\end{abstract}

Kata Kunci: Model Pictorial, Representasi Matematis, Soal Cerita Matematis

\section{PICTORIAL MODEL AS THE REPRESENTATION TO SOLVE MATHEMATICAL WORDS PROBLEM}

\begin{abstract}
This paper presents a study of the Pictorial model as a mathematical representation in solving mathematical words problem. The ability of mathematical representation is an important key for students in solving mathematical words problems and being successfull in mathematics learning. Therefore, this ability should be emphasized, developed and owned by students in learning mathematics. The Pictorial Model can be used as a first step in representing and simultaneously modeling/illustrating the purpose of a mathematical words problem. This Pictorial model approach combined with basic algebraic concepts is expected to be able to assist all students in understanding as well as solving mathematical description problems in which usually students find them difficult. In this way, students can ultimately develop their competencies and mathematical abilities optimally.
\end{abstract}

Keywords. Pictorial Model, Mathematical Representation, Mathematical Words Problem

\section{Pendahuluan}

Dalam proses pembelajaran matematika sering sekali kita temui siswa banyak mengalami kesulitan menyelesaikan berbagai soal matematis terlebih soal-soal cerita (verbal) dan 
pemecahan masalah (problem solving). Mengapa siswa mengalami kesulitan menyelesaikan soal-soal cerita tersebut?. Hal ini dapat ditilik dari karakteristik matematika sebagai ilmu yang terstruktur dan sistematis (Prianto, 2016:12) yang berarti susunan unsur-unsurnya terstruktur secara hierarkis dan terjalin hubungan fungsional yang erat (Hendriana \& Soemarno, 2014). Selain itu, matematika juga tidak bisa dipisahkan dari pola (patterns) dan berbagai hubungan (relationships) (Reys, 2009), dan juga matematika memiliki objek abstrak dan menggunakan berbagai simbol (Sumardyono 2014 \& As'ari, 2016).

Berbagai karakteristik matematika tersebut mengindikasikan bahwa dalam menyelesaikan berbagai soal cerita matematis, tidak cukup hanya menggunakan hafalan rumus atau keterampilan matematis semata. Hal ini disebabkan soal semacam ini memuat kalimat dan informasi yang perlu direpresentasikan terlebih dahulu sebelum permasalahan dapat dipecahkan. Sejatinya, hafal rumus kurang berarti jika soal cerita belum direpresentasikan dan diubah menjadi model dan kalimat matematika yang secara langsung terkait dengan rumus maupun prosedur penyelesaian soal tersebut (Al Krismanto, 2009). Selain itu, untuk menyelesaikan masalah (problem solving) termasuk soal cerita matematis juga diperlukan sejumlah langkah yang dilakukan secara bertahap dan runtut, yaitu (a) understanding the problem; (b) devising plan; (c) carrying out the plan; dan (d) looking back (Polya, 1988). Bagi siswa yang pemahaman konseptual dan kemampuan matematisnya tinggi, langkah ini sangat baik dan mudah diterapkan dalam menyelesaikan soal cerita. Namun dalam praktik sehari-hari, kemampuan matematis siswa beragam. Seringkali dijumpai banyak siswa yang mengalami kesulitan menyelesaikan soal cerita yang hanya menggunakan simbol-notasi sebagai langkah awal merepresentasikan informasi yang ada pada soal tersebut. Kemudikan dilakukan sejumlah langkah operasional dan keterampilan matematis sehingga ditemukan jawabannya.

Menurut Supap, Naruedomkul \& Cercone (2011), yang jauh lebih penting dibutuhkan dalam menyelesaikan soal cerita matematis adalah kecermatan membaca dan memahami soal ceritanya, mengidentifikasi berbagai informasi yang ada, mengidentifikasi pertanyaan yang disajikan. Selain itu juga membuat representasi dengan berbagai model matematika (pemodelan), memilih langkah-langkah yang akan digunakan, menerapkan operasi matematis secara benar, serta menyimpulkan jawaban secara tepat dan benar sesuai pertanyaan.

Untuk mengatasi mengatasi kesulitan siswa menyelesaikan soal cerita matematis, bagaimana solusi yang perlu dilakukan guru matematika untuk mengatasi kesulitan siswa menyelesaikan soal-soal cerita terutama bagi siswa dengan kemampuan matematis yang rendah sehingga memudahkan memahami, merepresentasikan dan menyelesaikan soal cerita tersebut? Apakah ada solusi yang lebih mudah diterima siswa untuk menyelesaikan soal-soal cerita? Tentunya guru matematika harus berusaha menangani permasalahan yang dihadapi siswa dan guru juga perlu mengambil langkah-langkah solutif agar siswa lebih mudah memahami dan menyelesaikan soal-soal cerita. 


\section{Representasi Matematis}

Representasi matematis merupakan salah satu standar proses dan aktivitas siswa dalam proses pembelajaran matematika sekolah (Princilpes and Standards for Mathetatics Education) (NCTM, 2000). Janvier (dalam Faruq, Yuwono \& Chandra, 2016:149-150) menyatakan representasi merupakan salah satu konsep psikologi yang digunakan dalam matematika untuk menjelaskan cara berpikir siswa. Standar dan tujuan utama representasi matematis di sekolah meliputi tiga hal "Instructional programs for representation as a process in school mathematics should enable all students to-(a) create and use representations to organize, record, and communicate mathematical ideas; (b) select, apply, and translate among mathematical representations to solve problems; \& (c) use representations to model and interpret physical, social, and mathematical phenomen"(NCTM, 2000:67 \& Reys, 2009:101-102). Representasi matematis sangat perlu ditekankan guru dalam proses pembelajaran matematika. Hal ini dikarenakan matematika merupakan ide abstrak. Karena ide abstrak, maka ide-ide matematis perlu direpresentasikan dengan beragam bentuk dan model bahkan berbeda-beda (As'ari, 2001:82).

Selain itu, kemampuan ini sangat penting bagi siswa dan erat kaitannya dengan kemampuan komunikasi matematis dan pemecahan masalah, dan juga dikarenakan setiap siswa pasti mempunyai pemahaman dan kemampuan matematis yang berbeda-beda. Pendekatan beragam representasi akan memudahkan siswa memahami konsep matematis dan menyelesaikan masalah. Pada dasarnya konsep representasi matematis terkait tiga teori, yaitu (a) teori Bruner: enative-iconic-symbolic; (b) teori Dienes: perceptual variability principle (Yoong, 2005: 295-296); dan (c) konsep Realistic Mathematics Education (RME) yaitu matematisasi (Yuwono, 2005 \& Wijaya, 2012). Terkait representasi matematis, Lesh \& Landau (dalam Reys, 2009:101) menjelaskan lima macam representasi konsep matematika (five representations for mathematical ideas), yaitu (a) pictures; (b) manipulatives; (c) relevant situations; (d) spoken language; dan (e) written symbols. Sedangkan Woong (1999) (dalam Yoong, 2005) menyajikan desain enam cara dalam representasi matematis yang disebut Multi-Model Strategy (MMS), yaitu (a) word (communicate); (b) number (calculate); (c) real thing (do); (d) diagram (visualise); (e) story (apply), dan (f) symbol (manipulate).

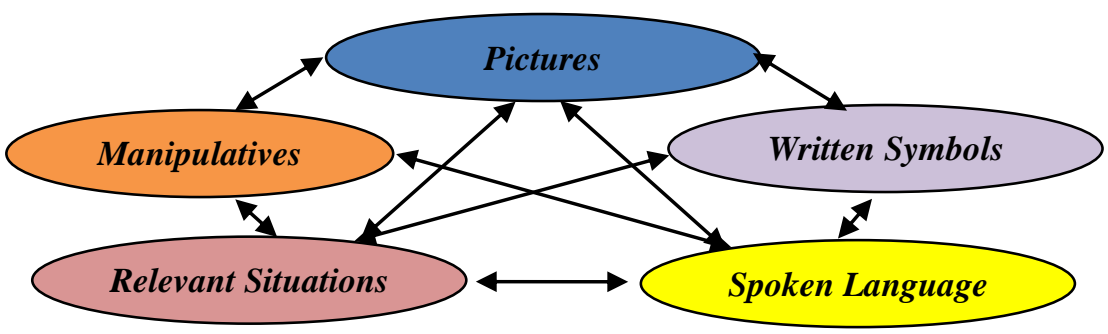

Gambar 1 Five Representations for Mathematical Ideas 


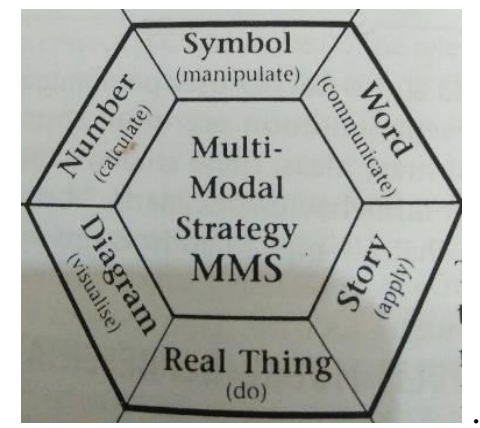

Gambar 2 Desain Multi-Model Strategy (MMS)

Ilustrasi desain enam cara representasi matematis dalam Multi-Model Strategy (MMS) disajikan Tabel 1 sebagai berikut.

Tabel 1 Ilustrasi dari Multi-Model Strategy

\begin{tabular}{|c|c|c|}
\hline No & Multi-Model Strategy & Ilustrasi \\
\hline a. & Word (communicate) & $\begin{array}{l}\text { Negatif lima ditambah positif tiga } \\
\text { sama dengan negatif dua }\end{array}$ \\
\hline b. & Number (calculate) & $-5+3=-2$ \\
\hline c. & Real thing (do) & $\begin{array}{c}\text { aktivitas menggunakan kartu berwarna atau aktivitas } \\
\text { berjalan maju-mundur }\end{array}$ \\
\hline $\mathrm{d}$. & Diagram (visualise) & $\underset{5 \cdot 5 \cdot 4 \cdot 3 \cdot 2 \cdot 1}{\stackrel{5}{\longrightarrow}}$ \\
\hline e. & Story (apply) & $\begin{array}{l}\text { Pagi ini, temperature/suhu menunjukkan negatif lima } \\
\text { dejarat Celcius. Siang hari suhu naik tiga derajat Celcius. } \\
\text { Berapakah suhu sekarang? }\end{array}$ \\
\hline f. & Symbol (manipulate) & $\begin{array}{c}-a+b=-(a-b), \text { jika } a>b \\
-a+b=b-a, \text { jika } b>a\end{array}$ \\
\hline
\end{tabular}

Berdasarkan ilustrasi dari Multi-Model Strategy (MMS) yang telah disajikan di atas menunjukkan betapa pentingnya representasi matematis bagi siswa dalam belajar matematika. Siswa dengan kemampuan representasi yang baik akan dapat membuat, menggunakan, mengaitkan, dan mengaplikasikan berbagai representasi matematis dengan beragam bentuk dan modelnya dari satu ide dan konsep matematis atau masalah yang disajikan. Hal inilah yang menjadi standar utama sekaligus tujuan utama representasi matematis yang diharapkan dikembangkan, dikuasai dan dimiliki siswa melalui belajar matematika di sekolah.

\section{Materi Ajabar}

Aljabar (Algebra) merupakan salah satu standar isi dan lingkup materi matematika sekolah yang harus diberikan dan pelajari siswa (NCTM, 2000 \& Permendikbud 21, 2016). Fokus 
materi aljabar yaitu mempelajari tentang berbagai struktur abstrak dan penggunaan prinsip struktur tersebut dalam menyelesaikan masalah (problem solving) yang dilambangkan dengan berbagai simbol (NCTM, 2000:37). Materi aljabar dipelajari siswa secara detail mulai jenjang SMP/MTs. Materi Aljabar sangat penting untuk dipelajari dan dikuasi siswa karena "Algebra is a powerful tool for representing information and solving problems" (Bennet, Burton, \& Nelson, 2010:37). Aljabar juga dapat digunakan untuk memecahkan berbagai permasalahan matematis aritmatika, soal-soal cerita, problem solving dan masalah sehari-hari. Dengan mempelajari dan menguasai materi aljabar siswa diharapkan (1) dapat memahami berbagai pola, hubungan, dan fungsi; (2) mampu menyatakan dan merepresentasikan masalah matematika dalam bentuk aljabar; dan (3) dapat menggunakan model matematika untuk memecahkan masalah (problem solving) (NCTM, 2000:37). Untuk berpikir aljabar, siswa harus mampu memahami pola, hubungan dan fungsi, menganalisis situasi matematika dan struktur yang menggunakan berbagai simbol. Aspek penting berpikir aljabar adalah kemampuan mempertimbangkan keterkaitan dan generalisasi dari situasi masalah. Berpikir aljabar didasarkan pada ide-ide dan konsep matematika dasar yang digunakan untuk memecahkan masalah (Prianto, 2015).

Dalam kajian materi aljabar, ada banyak istilah yang perlu pahami, diantaranya variabel, koefisien, konstanta, bentuk aljabar (algebraic expression), suku aljabar, suku sejenis, dan suku banyak (polynom) (Mower, 2013:2). Dengan bahasa simbol, dari relasi-relasi yang muncul dalam aljabar, soal-soal cerita dan masalah-masalah matematis dapat dipecahkan secara sederhana. Bahkan untuk hal-hal tertentu ada algoritma-algoritma yang mudah diikuti dalam rangka memecahkan masalah simbolik itu, yang pada saatnya nanti dikembalikan pada soal cerita matematis dan masalah sehari-hari (Al Krismanto, 2009:1).

\section{Model Pictorial sebagai Representasi Menyelesaikan Soal Cerita}

Keberhasilam siswa dalam penyelesaian masalah matematis termasuk soal cerita dapat diamati dan dinilai berdasarkan hasil konstruksi siswa dalam merepresentasikan suatu masalah dan menggunakan representasi tersebut dalam berbagai bentuk dan model, misalnya dengan kata-kata, grafik, tabel, simbol, notasi dan persamaan-persamaan matematika (Neria \& Amit, 2004). Krawec 2010) menjelaskan bahwa untuk penyelesaian masalah terutama soal cerita matematis terdapat tiga tahapan guna mengeksplorasi representasi matematis, yaitu (a) tahap translasi, yang berarti membaca soal cerita yang melibatkan transformasi dari pernyataan dan informasi soal menjadi bentuk lain; (b) tahap integrasi, yang berarti memvisualisasi berbagai ide berdasarkan soal cerita dengan membuat gambar, model atau skema; dan (c) tahap solusi, yang berarti menyajikan deskripsi komputasi dan langkah penyelesaian soal cerita tersebut. Lebih lanjut, Hegarty \& Kohzenikov (1999) menjelaskan dua tipe representasi terkait dengan keberhasilan siswa menyelesaikan soal cerita matematis, yaitu (a) representasi pictorial (pictorial representations), yaitu menampilkan secara visual (memvisualkan) objek dan informasi yang dijelaskan dalam soal cerita tersebut; dan (b) representasi skematik (scematic representations), yaitu mendeskripsikan hubungan spasial dalam soal cerita tersebut.

Salah satu langkah yang dapat jadikan sebagai solusi alternatif dalam menyelesaikan soal cerita matematis adalah menggunakan model Pictorial sebagai representasi matematis 
terhadap informasi dan objek berdasarkan soal cerita matematis yang disajikan. Tujuan dan fungsi utama model Pictorial adalah memvisualisasikan dan memodelkan secara matematis soal cerita sehingga mudah dipahami siswa yang selanjutnya dapat diformalisasikan dan ditransformasikan dalam bentuk simbol dan persamaan matematis (aljabar) guna menyelesaikan soal cerita tersebut (Hong, 2005:393). Model Pictorial juga sebagai salah suatu strategi menyelesaikan masalah (problem solving) (Yee, 2000:63). Konsep dasar model Pictorial ini diadapsi dari artikelnya Kho Tek Hong (2005) yang berjudul "The Model-Drawing Method with Algebra" dalam buku Teaching Primary School Mathematics: a Resource Book (2009) yang disajikan pada Tabel 2, Tabel 3 dan Tabel 4.

Tabel 2 Konsep Dasar Model Pictorial

\section{(1) Model Bagian-Keseluruhan}

Model ini menunjukkan hubungan antara keseluruhan dan bagiannya

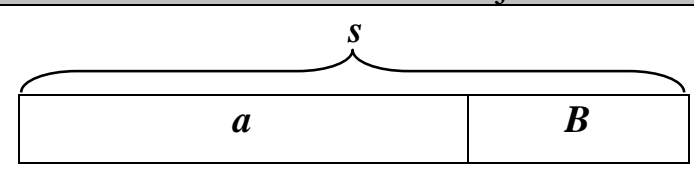

$\boldsymbol{s}$ dibagi dua bagian yaitu $\boldsymbol{a}$ dan $\boldsymbol{b}$ $s=a+b \Leftrightarrow a+b=s$

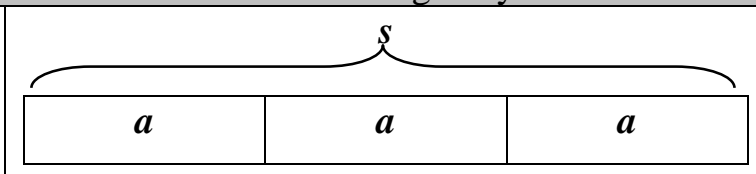

$\boldsymbol{s}$ dibagi tiga bagian sama yaitu $\boldsymbol{a}$ $s=a+a+a, s=3 a \Leftrightarrow 3 a=s$

(2) Model Perbandingan

Model ini sebagai hubungan dua kuantitas yang dibandingan

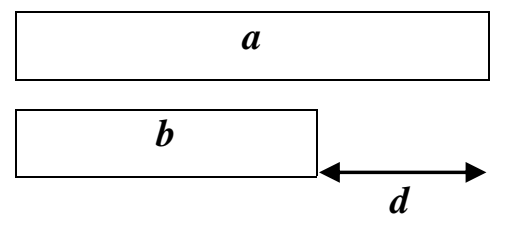

$\boldsymbol{a}$ lebih besar dari $\boldsymbol{b}$

$\boldsymbol{d}$ adalah hasil $\boldsymbol{a}$ kurang $\boldsymbol{b}$ $\boldsymbol{d}=\boldsymbol{a}-\boldsymbol{b}$

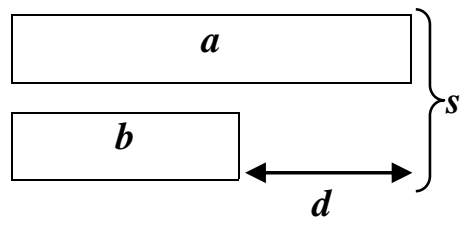

$\boldsymbol{s}$ adalah jumlah $\boldsymbol{a}$ dan $\boldsymbol{b}$ $s=a+b$
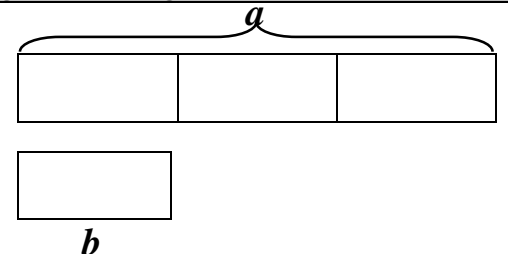

$\boldsymbol{a}$ adalah tiga kali $\boldsymbol{b}$ $\boldsymbol{a}=\mathbf{3 b}$

Berdasarkan Konsep Model Pictorial yang telah disajikan di atas akan digunakan untuk merepresentasikan beberapa soal cerita matematis yang selanjutnya akan diformulasikan dan diselesaikan dengan menggunakan konsep aljabar.

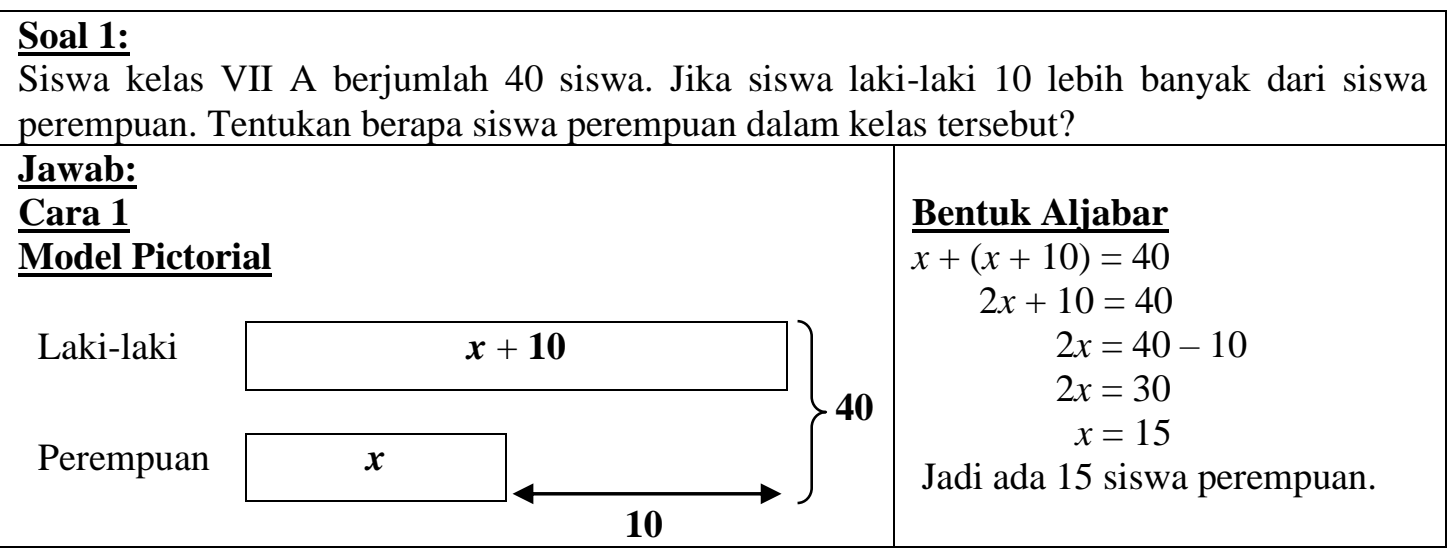




\section{Cara 2 \\ Model Pictorial}

Laki-laki

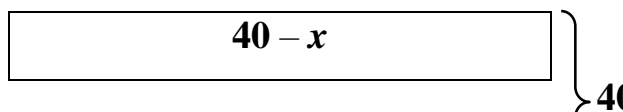

Perempuan

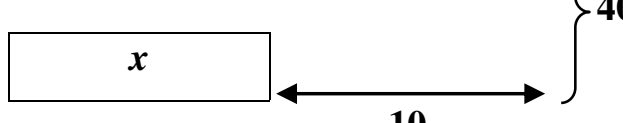

10

\section{Bentuk Aljabar}

$(40-x)-x=10$

$40-2 x=10$

$2 x=40-10$

$2 x=30$

$x=15$

Jadi ada 15 siswa perempuan.

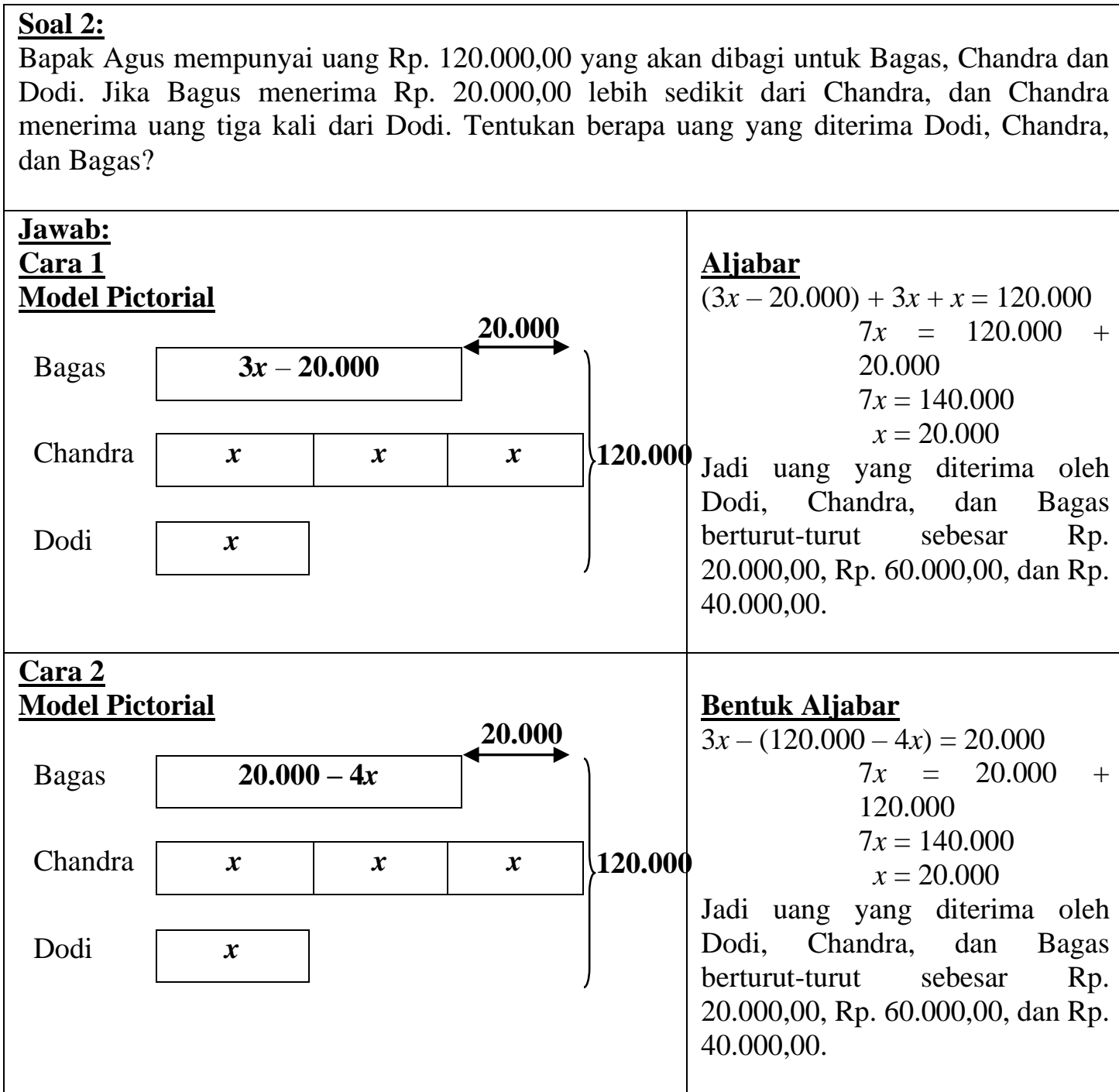




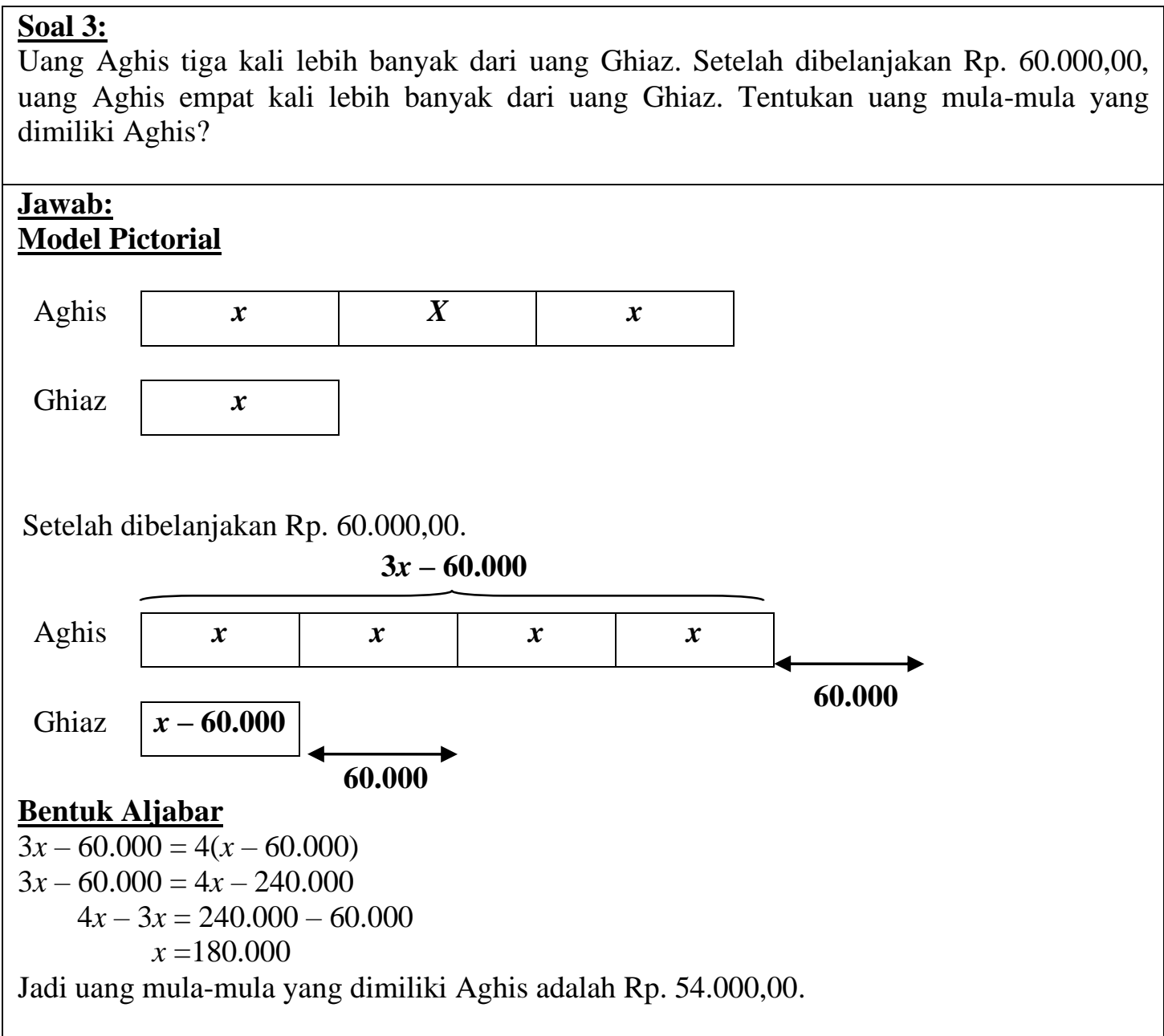

Tabel 3 Konsep Dasar Model Pictorial untuk Pecahan dan Perbandingan

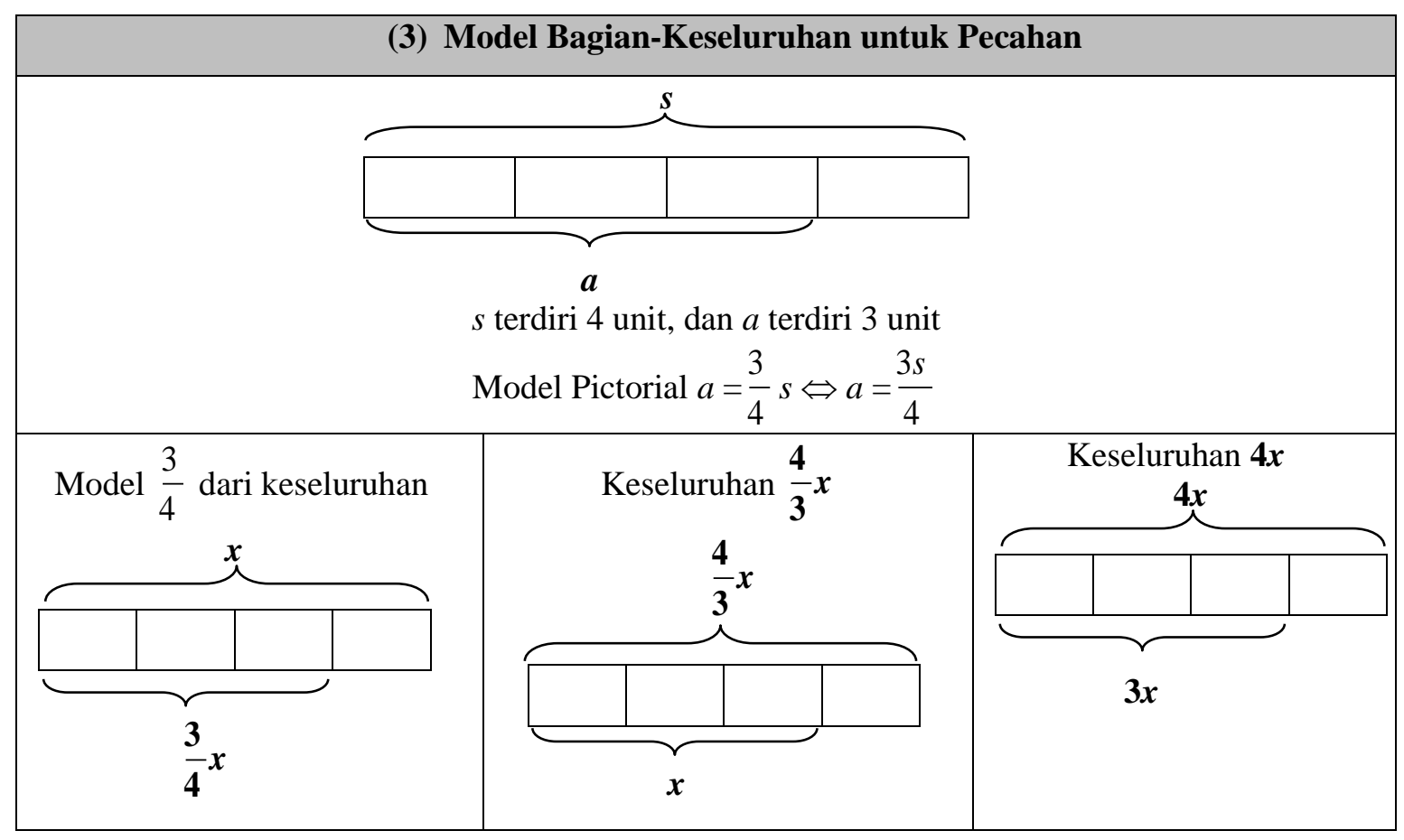




\section{(4) Model Perbandingan untuk Pecahan dan Rasio}

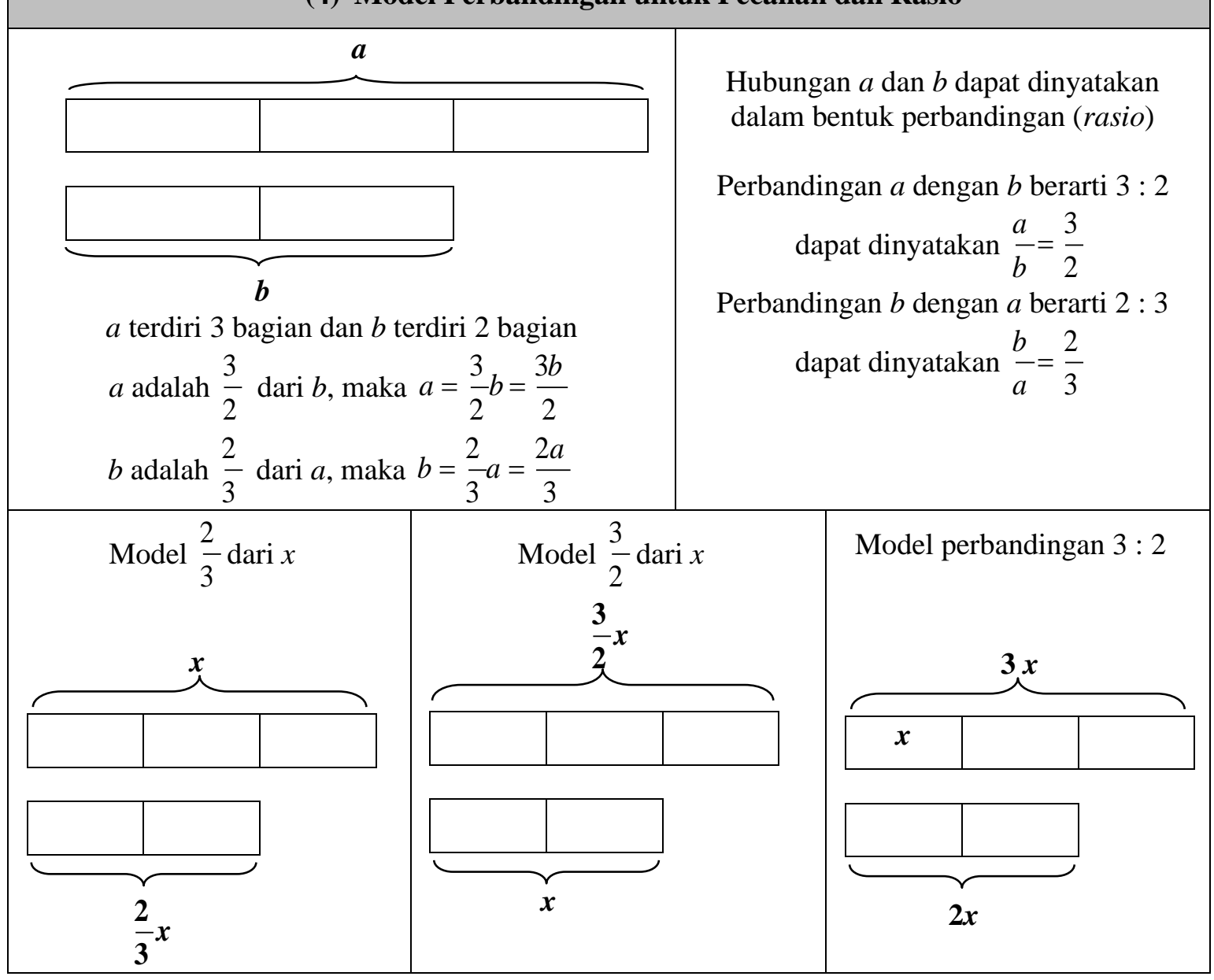

\section{Soal 4:}

Uang Agus $\frac{2}{3}$ lebih banyak dari Anis. Uang Anis menjadi Rp. 200.000,00 setelah menerima $\frac{1}{2}$ uang Agus. Berapa uang Agus mula-mula?

\section{Jawab:}

\section{Model Pictorial}

Mula-mula:

\begin{tabular}{l|l|l|}
\hline Agus & $\boldsymbol{X}$ & $\boldsymbol{x}$ \\
\hline
\end{tabular}

Anis

\begin{tabular}{|l|l|l|}
\hline$X$ & $x$ & $x$ \\
\hline
\end{tabular}

Setelahnya:

Agus

$\boldsymbol{X}$

Anis

\begin{tabular}{|l|l|l|l|}
\hline$X$ & $x$ & $x$ & $x$ \\
\hline
\end{tabular}

200.000 


\section{Bentuk Aljabar}

Mula-mula uang Agus $2 x$ dan uang Anis $3 x$ dapat dinyatakan $4 x=200.000$

$4 x=200.000$

$x=50.000$ (Uang Anis)

Uang Agus $2 x=$ Rp. 100.000,00

Jadi mula-mula uang Agus adalah Rp. 100.000,00.

\section{Soal 5:}

Dalam suatu kaleng terdapat $\frac{3}{5}$ kelereng kuning, sisanya kelereng merah dan biru. Perbandingan kelereng merah dan biru adalah $4: 5$. Jika ada sebanyak 30 kelereng biru, tentukan banyaknya kelereng kuning?

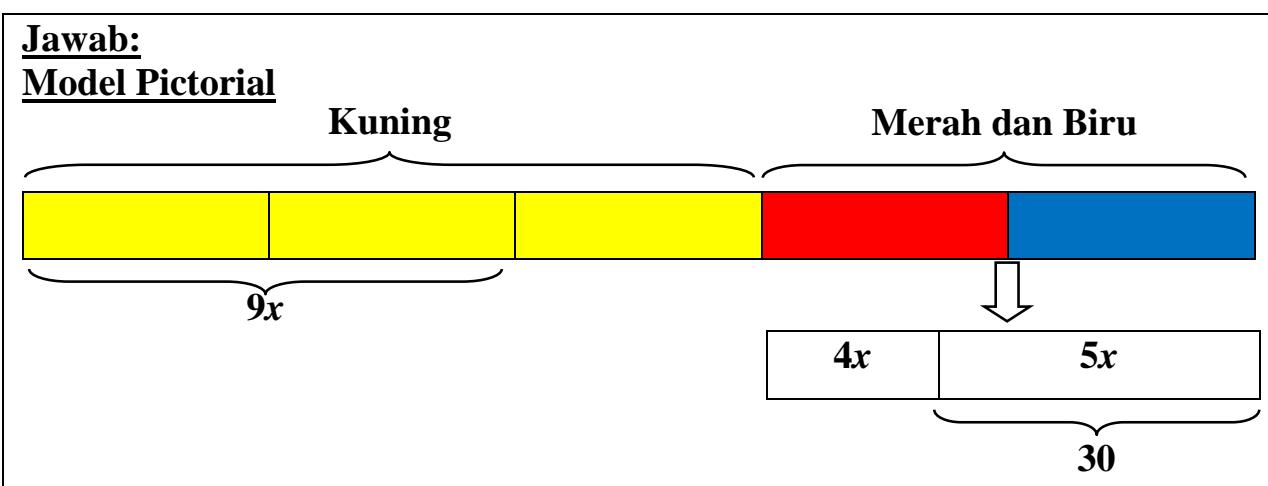

\section{Bentuk Aljabar}

Banyak kelereng merah dan kelereng biru $4 x$ dan $5 x$. Dapat dinyatakan $5 x=30$

$5 x=30$

$x=6$ (kelereng)

Banyak kelereng kuning $3\left(\frac{9 x}{2}\right)=\frac{27 x}{2}=\frac{27(6)}{2}=81$ kelereng

Jadi kelereng kuning sebanyak 81 kelereng.

Tabel 4: Konsep Dasar Model Pictorial untuk Persentase

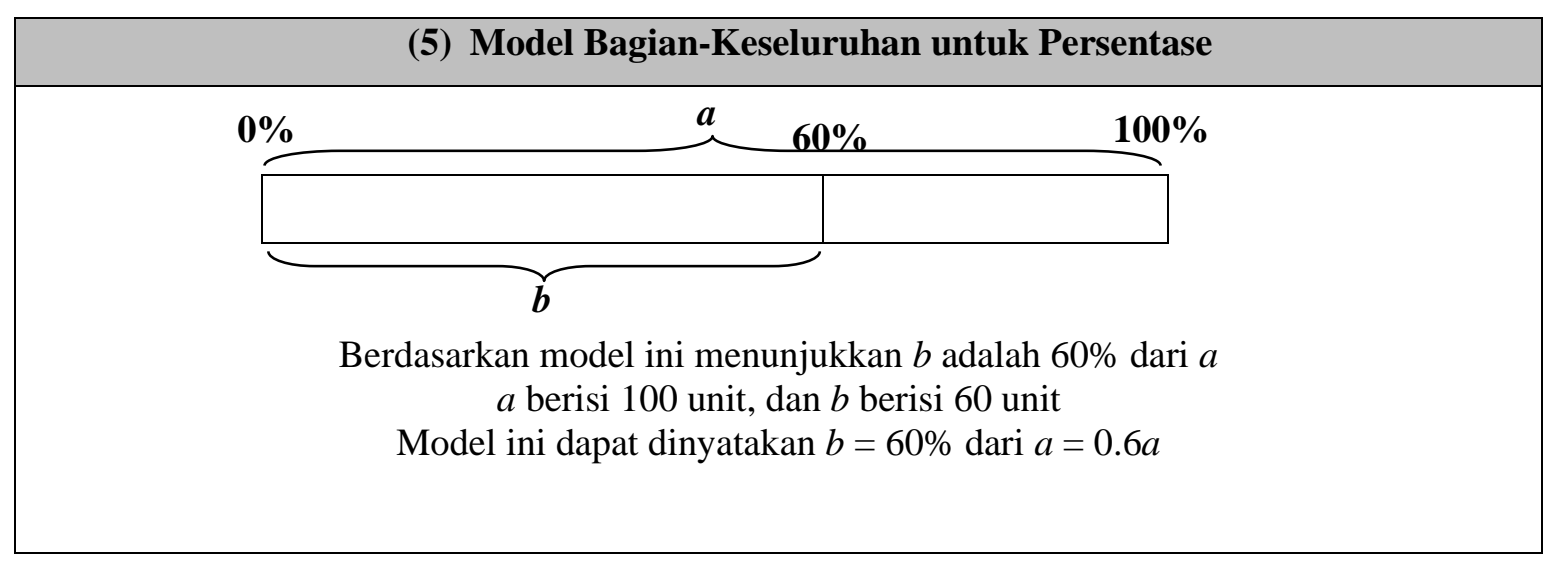




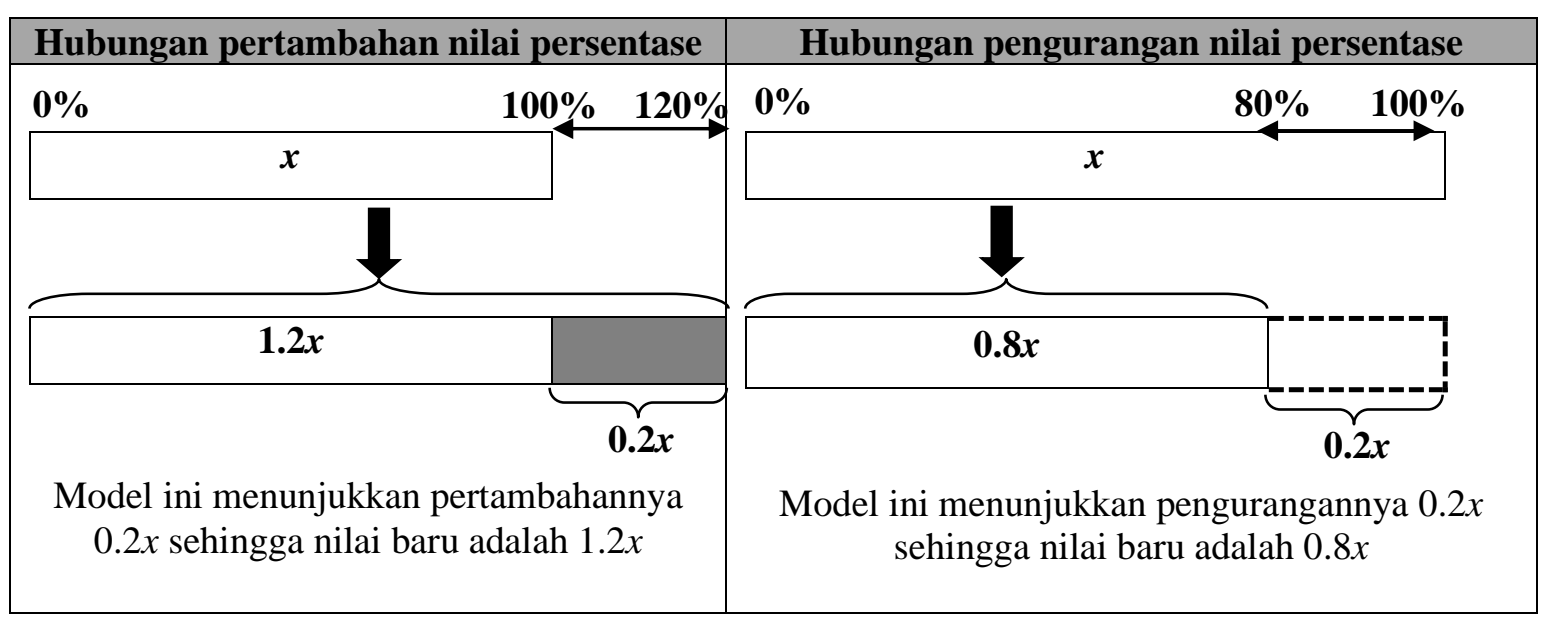

(6) Perbandingan untuk Persentase

\begin{tabular}{c}
\hline $\boldsymbol{0 \%}$ \\
\hline $\begin{array}{c}\text { Berdasarkan model ini menunjukkan } b \text { adalah } 120 \% \text { dari } a \\
a \text { berisi } 100 \text { unit, dan } b \text { berisi } 120 \text { unit } \\
\text { Model ini dapat dinyatakan } b=120 \% \text { dan } a=1.20 a \\
b \text { adalah 25\% lebih banyak dari } a\end{array}$ \\
\hline
\end{tabular}

\section{Soal 6:}

Bapak Agus membayar sewa hotel 1 malam dengan Kartu VIP Member dan mendapatkan diskon 30\%. Jika harga yang dibayar Rp.133.000,00. Berapa harga sewa hotel mula-mula?

\section{Jawab:}

\section{Model Pictorial}

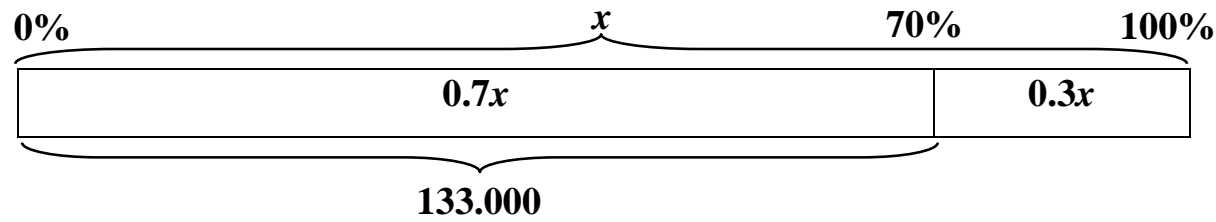

\section{Bentuk Aljabar}

Model tersebut dapat dinyatakan $0.7 x=133.000$

$0.7 x=133.000$

$x=190.000$

Jadi harga sewa hotel mula-mula Rp. 190.000,00. 


\section{Soal 7:}

Bapak Agus menghabiskan $\frac{2}{3}$ uangnya untuk membeli sepatu. Bapak Agus juga menghabiskan 40\% dari sisa uangnya untuk membayar sandal. Jika harga sepatu Rp. 80.000,00 lebih mahal dari harga sandal tersebut. Tentukan uang Bapak Agus sebelum digunakan untuk membayar sepatu dan sandal tersebut?

\section{Jawab:}

Model Pictorial

\section{Sepatu}

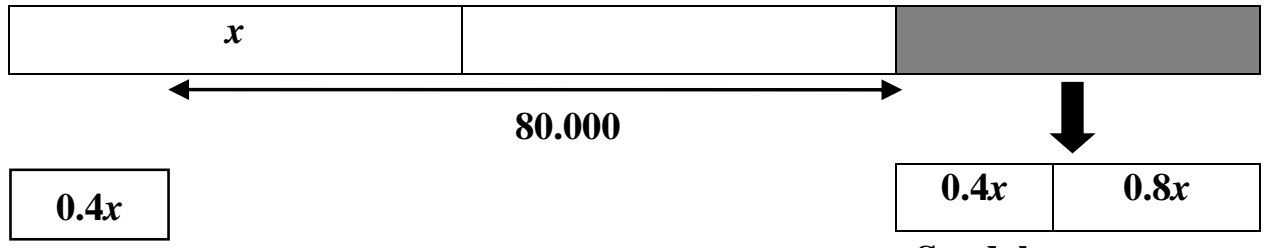

Sandal

\section{Bentuk Aljabar}

Uang Bapak Agus awalnya $3 x$. Model tersebut dapat dinyatakan $2 x-0,4 x=80.000$

$2 x-0,4 x=80.000$

$$
\begin{aligned}
1,6 x & =80.000 \\
x & =50.000
\end{aligned}
$$

Jadi uang Bapak Agus (awalnya) sebelum digunakan untuk membayar sepatu dan sandal tersebut Rp. $150.000,00$.

\section{Penutup}

Dalam proses penyelesaian soal pemecahan masalah (problem solving) yang berbentuk soal cerita matematika, sangat bergantung dengan kemampuan dan pemahaman matematis setiap siswa. Setiap siswa pasti mempunyai kemampuan matematis yang beragam dan berbedabeda. Disinilah pentingnya kemampuan membuat representasi matematis ditekankan bagi siswa selama proses pembelajaran matematika. Dengan kemampuan representasi matematis yang baik, siswa akan mampu membuat, menggunakan, mengaitkan, dan mengaplikasikan berbagai representasi matematis dengan beragam bentuk dan modelnya (word, number, real thing, diagram, story, \& symbol) dari satu ide-konsep matematis atau soal cerita matematis yang disajikan.

Penguasaan konsep aljabar merupakan kunci keberhasilan dalam mempelajari matematika yang lebih tinggi (Hong, 2005:411). Tetapi kemampuan representasi matematis merupakan central to the study of mathematics yang berarti sebagai kunci awal dan dasar siswa dalam keberhasilan menyelesaikan soal cerita matematis dan juga dalam belajar matematika. Model Pictorial dapat digunakan sebagai langkah awal merepresentasikan sekaligus memodelkan/mengilustrasikan maksud soal cerita matematis yang disajikan. Model ini sangat direkomendasikan dan dapat digunakan sebagai solusi alternatif bagi setiap siswa sebelum menyelesaikan soal cerita matematis. Pendekatan model Pictorial ini yang dipadukan dengan konsep aljabar dasar diharapkan akan dapat membantu semua siswa dalam memahami sekaligus menyelesaikan soal cerita matematis yang pada umumnya siswa 
mengalami kesulitan sehingga semua siswa dapat mengembangkan kompetensi dan kemampuan matematisnya secara optimal.

\section{Daftar Pustaka}

Al Krismanto. 2009. Modul Matematika SMP Program BERMUTU: Kapita Selekta Pembelajaran Aljabar di Kelas VII SMP. Yogyakarta: Pusat Pengembangan dan Pemberdayaan Pendidik dan Tenaga Kependidikan (PPPPTK) Matematika.

As'ari, A. R., dkk. 2016. Buku Guru Matematika: SMP/MTs Kelas VIII. (Kurikulum 2013 Edisi Revisi 2016). Jakarta: Kementerian Pendidikan dan Kebudayaan Republik Indonesia.

As'ari, A. R. 2001. Representasi: Pentingnya dalam Pembelajaran Matematika. Jurnal Matematika. Vol. 7(2). Hlm: 81-91.

Bennet Jr, A.B., Burton, L.J., \& Nelson, L, T. 2010. Mathematics for Elementasry Teachers: $a$ Conceptual Approach. (9 $9^{\text {th }}$ Edition). The McGraw-Hill Companies, Inc.

Faruq, A., Yuwono, I., \& Chandra, T. D. 2016. Representasi (Eksternal-Internal) pada Penyelesaian Masalah Matematika. Jurnal Review Pembelajaran Matematika (JRPM). Vol. 1. No. 2. Desember 2016. Hlm: 149-162.

Hegarty, M., \& Kozhevnikov, M. 1999. Types of Visual-Spatial Representations and Mathematical Problem Solving. Journal of Educational Psychology. Vol. 91(4). Hlm: 684-689.

Hendriana, H \& Soemarmo, U. 2014. Penilaian Pembelajaran Matematika. Bandung: PT. Refina Aditama.

Hong, K. T. 2005. The Model-Drawing Method with Algebra. Hlm:393-413. Artikel dalam Buku Teaching Secondary School Mathematics: a Resource Book (Second Edition). (2009). (Edited: Lee Peng Yee \& Lee Ngan Hoe). Singapore: McGraw-Hill Education.

Krawec, J. L. 2010. Problem Representation and Mathematical Problem Solving of Students of Varying Math Ability. Open Access Dissertations. Paper 455. Miami: University of Miami.

Mower, P. 2013. Pre-Algebra Out Loud: Learning Mathematics through Reading and Writing Activities. San Francisco: John Wiley \& Sons, Inc.

Neria, D., \& Amit, M. 2004. Students Preference of Non-Algebraic Representations in Mathematical Communication. In Proceedings of the $28^{\text {th }}$ Conference of the International Group for the Psychology of Mathematics Education. Vol.3. Hlm: 409-416.

Permendikbud 21 Tahun 2016 Tentang Standar Isi Pelajaran Matematika SMP/MTs/SLB.

Prianto, A. 2015. Kajian Materi Aljabar dan Komunikasi Matematis. Jurnal IDEAL MATHEDU (Indonesian Digital Journal of Mathematics and Education). Volume 2. Edisi 2. Tahun 2015. Hlm: 115-122. Yogyakarta: Pusat Pengembangan dan Pemberdayaan Pendidik dan Tenaga Kependidikan (PPPPTK) Matematika.

Prianto, A. 2016. Koneksi Matematis. Buletin LIMAS. Edisi Nomor 35. November 2016. Hlm: 12-17. Yogyakarta: Pusat Pengembangan dan Pemberdayaan Pendidik dan Tenaga Kependidikan (PPPPTK) Matematika.

Reys, R., Lindquist, M.M., Lambdin, D.V., \& Smith, N.L. 2009. Helping Children Learn Mathematics. ( $9^{\text {th }}$ Edition). The United States of America: John Wiley \& Sons, Inc.

Sumardyono. 2004. Karakteristik Matematika dan Implikasinya terhadap Pembelajaran Matematika. Yogyakarta: Pusat Pengembangan dan Pemberdayaan Pendidik dan Tenaga Kependidikan (PPPPTK) Matematika.

Supap, W., Naruedomkul, K., \& Cercone, N. 2011. Automatic Learning Guide for Mathematical Word Problem. The International Journal of Learning. Vol. 17. No. 11.

Wijaya, A. 2012. Pendidikan Matematika Realistik: Suatu Alternatif Pendekatan Pembelajaran Matematika. Yogyakarta: Graha Ilmu. 
Yee, F. P. 2009. Problem Solving in Mathematics. Hlm: 54-81. Artikel dalam Teaching Primary School Mathematics: a Resource Book (Second Edition). (2009). (Edited: Lee Peng Yee \& Lee Ngan Hoe). Singapore: McGraw-Hill Education.

Yoong, W. K. 2005. Learning Theories for Mathematics Education. Hlm: 292-304. Artikel dalam Teaching Secondary School Mathematics: a Resource Book (Second Edition). (2009). (Edited: Lee Peng Yee \& Lee Ngan Hoe). Singapore: McGraw-Hill Education.

Yuwono, I. 2005. Pembelajaran Matematika secara Membumi. Malang: Universitas Negeri Malang. 